\title{
Corporate Social Responsibility, and Employee Commitment in Libyan
}

\author{
Tamer M. Alkadash ${ }^{1 *}$, Saleem Mohammed Aljileedi ${ }^{2}$ \\ * Assistant Professor, Gulf University. \\ ${ }^{2}$ Limkokwing University of Creative Technology, Malaysia.
}

\author{
Article Info \\ Article history: \\ Received 29 December 2019 \\ Received in revised form 20 January 2020 \\ Accepted 15 March 2020 \\ Published 01 April 2020
}

\begin{abstract}
This study's main objective was to explore the influence of Corporate Social Responsibility on employees, customers, environment, and community on employees' commitment to the organization in the construction industry in Libya. This study as well allows the researchers to understand and how the association of Corporate Social Responsibility (CSR) influenced employees in the Libyan construction industry. The study used descriptive analyzes are often used to describe and convert the general characteristics of data to evaluate their distribution, variability, and central trend. It also guides a large number of respondents to evaluate and interpret their answers to identify their characteristics after the research sample has been received. The limitation of this study is that the questionnaire could be answered only by those familiar with the English language, and the information provided by the respondents is presumed true.
\end{abstract}

Keywords: Corporate Social Responsibility, Employee Commitment, Libya, Environment, Community, Employee, Customer

\section{Introduction}

Corporate Social Responsibility (CSR) presents an advantage as a key issue within the global business community and currently holds the core business. It focuses more on corporate social responsibility in customer, employee, and community relationships between organizations and stakeholders. Today, corporate leaders are concerned with social responsibility and issues such as employee health, safety, environment, and wellbeing. CSR concerns the transparency or openness of a company and takes into account the expectations of its stakeholders. This means that companies are selfish and more than social responsibility (Mazutis \& Slawinski, 2015). Businesses can no longer function completely independently and must consider the social and social needs of their communities. Organizations now recognize that they need to exercise social responsibility to survive, remain unique in their work, and receive their calculated benefits. To find a sustainable business, large organizations include corporate social responsibility in their calculated plans. Large companies have a more effective impact on society today, but SMEs are major businesses that have a large impact on society because they are the largest and most dominant companies and employers in the majority of economies. The present life is gathered together with different themes, including universal exchange, dangerous atmospheric deviation, normal fiascos: vitality supply concerns, innovation, and social concerns. In any case, before the ongoing worldwide downturn, which has shaken business pioneers to think, they are socially dependable while working together and making benefits, CSR was primarily seen in creating nations (Dong, 2016). An association's duty isn't implemented by law and other exchange or association contracts and towards all aspects of the general public and gatherings of investors. As indicated by another academician, Corporate social obligation (CSR) is depicted as the conservative, legitimate, and moral desires that society has any time from association (Jain et al., 2018). According to Carroll (1991), Corporate Social Responsibility (CSR) is defined as social responsibility, but at the same time, this was not embraced in the current study. As there are other researchers also explained, the term beyond the above-mentioned constructs and Walton (1967) defined this as an act of voluntarism.' Whilst in the developed countries, the CSR appeared to push and monitor larger organizations, the CSR was not only limited to economic and legal liabilities, as Carroll (1979) identified the two main factors in CSR. Werther Jr \& Chandler (2010) have also argued that CSR is a way of alleviating financial and operational limitations on business in today's world where all people and organizations are seeking to make changes. Several complicated occasions are involved in the construction project. Stakeholders in projects in which the participating enterprises have several types and attitudes of various interests and expenses. The importance and definitions of the Kennedy School of Government (2011) and academics like a scholar (Olander \& Landin, 2005; Callan \& Thomas, 2011) are evidence of the interplay between the acting curiosity and the Corporate Social Responsibility (CSR) in terms of construction. The science star Peter Drucker argues that the 21st century will be an era of social connections. 
Today in the Middle East, and particularly in Libya, corporate Social Responsibility (CSR) is certainly visible in Arab countries. The main reason is that, although Libya has gradually begun to understand the Corporate Social Responsibility (CSR) idea and are interested in Corporate Social Responsibility (CSR) activities within certain Arab countries in the region, the Corporate Social Responsibility (CSR) is not begun. The goal of Corporate Social Responsibility (CSR) implementation as a strategic instrument to improve business relations in Libya is to improve relations with employees (Abugre \& Anlesinya, 2019). Leading companies used Corporate Social Responsibility (CSR) to establish a good relationship with the outside and also with the inside. For example, employees assess the company's Corporate Social Responsibility (CSR) as a good tool to assess Libya's commitment and performance in the company. There is still room for further development, however. This specific analysis will provide the scientific answer to obtaining an immediate evaluation of Corporate Social Responsibility (CSR) methods by providing a guide to the company employees' commitment, which will ultimately influence the organization's functionality.

People are now free to go and get away from work quite simply, so companies have pressure on keeping their employees as long as possible. A report by Li et al. (2018) focuses on the internal employee stakeholders and the extent to which they participate in selecting community business. While the issues in the management of a construction company are well-known, which have made the employees authentic, there is little understanding that non-profit stakeholders and managers assess the views of the employees and are, therefore, interested in selecting appropriate issues (Li et al., 2018). That is why the construction company must look at stakeholders and take their perceptions into account. Internal employees must know what the company does, which requires that its employees concentrate their company's advertising efforts. In this particular context, encouraging society's social responsibility while motivating employees to get involved in these pursuits allows businesses to produce a good link with the employees. It is based on observations that a longer organizational commitment offers businesses advantages to justify the link between methods of social responsibility and the commitment of employees. In particular, the company is thought to reduce turnover and absence, increase employee productivity and business performance while also attracting candidate groups. O'Reilly \& Chatman (1986) 's work provides explicit standard values between the organization and its staff to enhance corporate engagement. The conclusion gives this study the chance to explore Corporate Social Responsibility (CSR) processes (as one of the main stakeholders) to employees, as well as employees ' commitment to the Libyan construction sector organization. Merely a few studies have been conducted in Libya to investigate the Corporate Social Responsibility (CSR) impact on employees, especially in commitment. Therefore, this still will do an empirical investigation of that. Expanded interest in Corporate Social Responsibility (CSR) is evident in the entire Libyan business for positive social change. Past investigations concentrated on venture returns (return for money invested), partner demands, ecological effects, and even legitimate effects identified with Corporate Social Responsibility (CSR). Sadly, most past research contemplated the dedication of representatives to the association in zones other than the zone of the effect of Corporate Social Responsibility (CSR). Furthermore, while every one of these fields of research is positively significant to more readily comprehend Corporate Social Responsibility (CSR), it appears that when all is said in done writing, the most significant issue of social effect has not been investigated in Libya and practically non-existent (Ali \& Frynas, 2018). The vast majority of the exploration on corporate social responsibility (CSR) spins around money-related execution, purchaser conduct, and effect on nature, for instance (Misani, 2017; Lindgreen et al., 2016) have examined relations between social duty. This study's main objective was to explore the influence of Corporate Social Responsibility on employees, customers, environment, and community on employees' commitment to the organization in the construction industry in Libya. This study as well allows the researchers to understand and how the association of Corporate Social Responsibility (CSR) influenced employees in the Libyan construction industry.

\section{Literature Review}

\subsection{Benefits of Carrying Out Corporate Social Responsibility}

It is easily found that CSR is used to improve or change the image of a company by internal staff when they are directly involved in the strategies developed to achieve CSR. Internally, in the successful execution of programs in favor of CSR, the company increases the loyalty and commitment of its employees, attracts trained professional personnel, improves the work environment, which increases productivity, profitability, and quality; it also helps to decrease operating costs, as well as financial security and environmental risks; Finally, it generates satisfaction and improves internal communication (Parra et al., 2016). Until a few years ago, it was believed that the business environment pursued purely economic objectives, where the maximization of the wealth of partners and investors corresponded to a primary objective within profit organizations. This purpose surpassed any other type of interest towards its agents of interaction, in which it was still impossible to disrupt integrative aspects reflected in actions and attitudes that involved said external agents "apparently" from the vision and approach of the companies.

Thus, the relationship between a company and society is that a company is a social entity. Companies are tightly connected, live, and survive with social institutions, organizations, and their environment. In other words, companies and society are interdependent. Companies are alive and alive in society, and by living in society, they survive and survive and show their value. Therefore, companies align and harmonize the purpose, vision, goals, and philosophy of the 
company with society's values, norms, and cultures, including nature, which is the foundation of society's survival. It is important to contribute to the amplification of social value. In this way, a company's role in establishing a relationship with society and contributing to society is its role. In other words, the question is how to deal with society.

According to Sakurai \& Hashimoto (2009), modern companies are under the following corporate environment and strongly influenced. The first is the progress of industrialization. In the course of industrialization, companies have made significant contributions, such as realizing economic prosperity and developing technological innovations. However, on the other hand, behaviors subject to social criticism such as natural destruction and environmental pollution.

\subsection{Commitment}

For employees to have the capacity to react to organization objectives, they initially must be propelled and dedicated to defeating the difficulties to accomplish the objective. The key component in inspiration is objectively defining; it is difficult to gauge the accomplishment without an objective. Inspiration is the thing that instigates the activity and answers the inquiries "for what reason am I doing this?" and "what do I plan to accomplish?". Employee commitment alludes to "the people's association and fulfillment with, just as excited for, work." The responsibility of the employees influences the efficiency and productivity by keeping up a positive association with the employees (Schepers et al., 2016). This has an impact on consumer loyalty. A method for submitting employees is to enable them by giving obligations and chances to influence their workplace. Comparatively, Argyris (1998) contends that no vision or system can become without equipped and empower employees. Empowered employees are needed and required for organizations to achieve their objectives and be financially healthy and environmentally responsible. In contrast with "not powered employees," further empowered employees are increasingly dedicated to partaking in natural exercises. A route for managers to support employees' empowerment is to rearrange the organization's structure to a horizontal organization rather than being a hierarchy. This gives the employees more opportunities to partake in basic leadership and take their own choices, resulting in more viability (Kesse Appiah, 2020). Cooperation is another important factor in crafted by achieving duty among employees to CSR activities. It is a great idea to create thoughts, evolve learning background, and improve the comprehension of why, what, how, where, and when to seek ideal environmental alternatives. Compensating the framework is another imperative factor that can help elevate employees to perform environmental practice, which can inspire and expand employee commitment. The compensating framework can be a method for submitting employees to the organization's environmental performance; instances of this are profit-sharing, increment in payor different advantages that propel (Ahmad, 2017); It should also meet the employee's requirements. Commitment alludes to that state where an individual received a certain arrangement of activities to accomplish the ideal target. Employee commitment is characterized as when employees assemble a mental connection to their association. Commitment occurs out at the degree employees fabricate recognizable proof and show a contribution to applicable undertakings in the working environment. Kanter \& Schneider (2013) conceptualized commitment as cohesion commitment, which is portrayed as the individual reserve of action and feeling to the gathering. Buchanan (1974) characterized commitment as far as divided duty where the employees show connection and perform jobs in harmoniousness with the association's objectives and qualities. Employee commitment demonstrated the relationship, including the sentiments and convictions of employees with the associations. Employee commitment confines to objectives and qualities compatibility as well as incorporates a need, longing, and commitment to demonstrate the linkage with the association. A full feeling of responsibility alludes to that state where employees want to stay at the association; the definition is comparable which Meyer \& Allen (1991) characterized. Continuation commitment happens dependent on the potential expenses related to leaving the association or absence of work openings, though standardizing duty happens as a feeling of commitment towards the association. A considerable assortment of proof has been accumulated concerning the three constructs of employees' commitment to the relationship to different factors(Alkadash, 2020). The three constructs are not fundamentally unrelated; rather, they exist on various occasions and all the while to a fluctuating degree at one time. As indicated by Meyer \& Maltin (2010), the past research demonstrates the solid relationship amongst full of feeling and regulating responsibilities concerning the connection. Be that as it may, the relationship among the three develops continuation duty. Both full of feeling responsibility and standardizing responsibility are observed to be progressively unassuming. The different creators bolster the three-dimensionality model of responsibility (Allen \& Meyer, 1996; Meyer et al., 1993; Meyer et al., 1990). A few issues that have raised analysis are the solid connection between affective and normative commitment. Because of solid relationships amongst affective and normative commitment, Solinger et al. (2008) face the issue of independence between the two types of commitment. The affective commitment among the three parts of commitment represents the identification, mental connection, and inclusion in the associations. Kim et al. (2010) takes affective commitment promise to interface the representative organization distinguishing proof and employee commitment and found that affective commitment is a critical pointer to characterize employee organization identification and employee commitment among the three development of responsibility. Recognizable proof of employees happens when they create a feeling of belongingness to a specific association. Meyer et al. (2006) examined distinguishing proof and affective commitment to the association, feeling of belongingness, and work conduct. To depict the relationship of the representative's identification and affective commitment to the association, they found a huge connection between these factors even though they utilize one element of recognizable proof. 


\section{Data Analysis}

In research studies, descriptive analyzes are often used to describe and convert the general characteristics of data to evaluate their distribution, variability, and central trend. It also guides a large number of respondents to evaluate and interpret their answers to identify their characteristics after the research sample has been received. This study shows that gender, age, tenure, and annual incomes were general characteristics of random employees from construction organizations. Around $28.3 \%$ of those who responded were female and $71.7 \%$ were male, $75.5 \%$ were married, and $24.5 \%$ were married. The majority were between 26 and 35 years of age (51,9\%), while $26,4 \%$ were between 16 and 25 years of age. $19.8 \%$ between $36-45$ years old and the remaining $1.9 \%$ between 46 years and older. Eighty-six percent $(85.8$ percent) of all respondents and employees who worked for their organizations for less than ten years represented 14.2 percent (17.3 percent) of all respondents. For the respondents' educational qualification, $86 \%$ of employees with a bachelor's degree (85.8\%) were the majority of the total participants. Master's degree employees accounted for 7.5 percent, and other grades, e.g., Diplomas, PhDs, and other professional certificates, were 6.6 percent. For the annual income of respondents, LYD 20,000-LYD 29,999 employees were the highest with an annual income of 31,1\% Annual income for LYD 10, 000 -LYD 19,999 employees accounted for $29.2 \%$ of the total number of respondents and LYD 10,000 annual income employees were $22.6 \%$ of the total. Furthermore, 9,4 percent of the total respondents were employees with annual income between LYD 30.000 and LYD 50.000, and 7,5 percent of the rest did not want to specify their annual income for the remainder.

\section{Reliability and Validity Analysis}

Scales that are reliable to be included in the study should be found. One of the principal issues is the internal consistency of the scale, which refers to the extent to which the measured items interconnect and measure the same underlying structure. Reliability ensures consistent measurements and indicates measured object stability, and helps to evaluate the measurement's validity.

Cronbach's Alpha coefficient is the most common indicator of these consistencies. The reliability of a sample depends on its sample, and it is necessary to verify that each sample is reliable. The reliability test of the survey forms was used by SPSS to evaluate the results obtained and to identify the variables as:
a) CSR to Environment (EN) and Community (CO)
b) CSR to Customers (CU)
c) CSR to Employees (EM)

Table 1. Reliability Analysis of Research Variables

\begin{tabular}{l|l|l|l}
\hline \multicolumn{1}{c|}{ Construct Item } & $\begin{array}{l}\text { Corrected Item- } \\
\text { Total Correlation }\end{array}$ & $\begin{array}{l}\text { Cronbach's Alpha if } \\
\text { item Deleted }\end{array}$ & $\begin{array}{l}\text { Construct } \\
\text { Reliability }\end{array}$ \\
\hline EN & & & $\mathbf{0 . 9 4 3}$ \\
EN1 & 0.836 & 0.932 & \\
EN2 & 0.830 & 0.932 & 0.935 \\
EN3 & 0.808 & 0.934 & \\
EN4 & 0.817 & 0.929 & \\
EN5 & 0.861 & 0.934 & \\
EN6 & 0.820 & & $\mathbf{0 . 5 9 8}$ \\
CO & & 0.580 & \\
CO7 & 0.244 & 0.526 & \\
CO8 & 0.413 & 0.549 & \\
CO9 & 0.348 & 0.592 & \\
CO10 & 0.196 & 0.526 & \\
CO11 & 0.421 & 0.530 & \\
CO12 & 0.402 & 0.583 & \\
CO13 & 0.234 & 0.617 & \\
CO14 & 0.117 & & $\mathbf{0 . 8 1 6}$ \\
\hline CU & & 0.708 & \\
CU3 & 0.757 & 0.698 & \\
CU4 & 0.775 & 0.740 & $\mathbf{0 . 8 6 8}$ \\
CU5 & 0.698 & 0.880 & \\
CU6 & 0.344 & 0.862 & \\
\hline EM & 0.494 & 0.859 & \\
EM1 & 0.591 & & \\
EM2 & & & \\
\hline
\end{tabular}




\begin{tabular}{l|l|l|l}
\hline \multicolumn{1}{c|}{ Construct Item } & $\begin{array}{l}\text { Corrected Item- } \\
\text { Total Correlation }\end{array}$ & $\begin{array}{l}\text { Cronbach's Alpha if } \\
\text { item Deleted }\end{array}$ & $\begin{array}{l}\text { Construct } \\
\text { Reliability }\end{array}$ \\
\hline EM3 & 0.312 & 0.868 & \\
EM4 & 0.538 & 0.860 & \\
EM5 & 0.486 & 0.861 & \\
EM6 & 0.021 & 0.882 & \\
EM7 & 0.571 & 0.860 & \\
EM8 & 0.596 & 0.859 & \\
EM9 & 0.521 & 0.861 & \\
EM10 & 0.591 & 0.858 & \\
EM11 & 0.478 & 0.862 & \\
\hline
\end{tabular}

Following the mentioned reliability analysis table, overall constructs have a reliability rate above 0.60 , but this shows the internal consistency of constructs; the CO construct reveals a reliability value of 0.598 , which is less than 0.60 .0 .60 was the cut-off value for reliability analysis.

Since the reliability analysis's cut-off value should be over 0.60 , the $\mathrm{CO}$ construct should, therefore, be re-evaluated to achieve a reliability value above 0.60 . Besides, the CO construct reveals the lowest value of 0.117 among other measured buildings when comparing the corrected item-total correlation. To make this re-evaluation, an item showing that the Alpha value in Cronbach was greater than 0.60 after the results were deleted, and that item, specifically CO14, evaluated the community's genuine opinion of organizations. This elimination ultimately explains that the community has probably not seen the organization negatively but rather positively.

The above item was subsequently removed, and the reliability of the CO construct was evaluated. It was also shown that the reliability value should be more than 60, which explains the construct's inner consistency following the removal of the particular item in this construct. Another reliability analysis was conducted after this change. The reassessed reliability analysis performed for the OC construct is shown in the table.

Table 2. Scale Statistics (Revised CO Construct)

\begin{tabular}{c|c|c|c}
\hline Construct Item & $\begin{array}{c}\text { Corrected Item-Total } \\
\text { Correlation }\end{array}$ & $\begin{array}{c}\text { Cronbach's Alpha if } \\
\text { item Deleted }\end{array}$ \\
\hline CO & & 0.652 \\
RO7 & 0.054 & 0.474 \\
CO8 & 0.594 & 0.513 \\
CO9 & 0.509 & 0.665 \\
CO10 & 0.017 & 0.500 \\
CO11 & 0.550 & 0.486 \\
CO12 & 0.570 & 0.669 \\
\hline
\end{tabular}

\section{Correlation Analysis}

The strength and direction of the linear relationship between two variables are used to describe correlations analysis. The analysis of correlations determines better knowledge of the data. Pearson Correlation Coefficient was used to analyze if the variables correlate with their linear relation level.

This coefficient shows how the linear relationship between two variables is directed and strong. The Pearson coefficient of correlation (r) may be between- 1 and +1 . The greater the value, the stronger the connection. A factor of + 1 shows a perfect positive relationship, and a factor of- 1 points to a perfect negative relation. Dispersion of this relation would reveal a straight line. It shows that the variables do not have a linear relationship. A dispersion would show a circle of points without any obvious pattern.

The values for interpretation according to statistics are as follows:

- $\quad$ Rho $=.10$ to .29 or -.10 to -.29 (small effect)

- $\quad$ Rho $=.30$ to .49 or -.30 to -.49 (medium effect)

- $\mathrm{Rho}=.50$ to 1.0 or -.50 to -1.0 (large effect)

\subsection{Correlation between CSR to environment and community towards Employees' Commitment}

The link was investigated between the employees' environmental CSR perceptions and the community (measured by the CSR to the community) and the commitment of the employees (measured by Total Employees' Commitments). CSR's variables to the environment and CSR to the community were correlated with total commitment of employees ( $\mathrm{r}=.520$, $0.222, \mathrm{n}=106, \mathrm{p}<.05)$, high environmental perception, and community levels associated with commitment of employees. 
Table 3. Correlation Matrix between CSR to environment and community towards Employees' Commitment

\begin{tabular}{|c|c|c|}
\hline & & $\begin{array}{l}\text { Total } \\
\text { employees' } \\
\text { commitment }\end{array}$ \\
\hline CSR to environment & $\begin{array}{l}\text { Pearson Correlation } \\
\text { Sig. (2-tailed) } \\
\mathrm{N}\end{array}$ & $\begin{array}{l}.520^{* *} \\
.000 \\
106\end{array}$ \\
\hline CSR to community & $\begin{array}{l}\text { Pearson Correlation } \\
\text { Sig. (2-tailed) } \\
\mathrm{N}\end{array}$ & $\begin{array}{l}.222^{*} \\
.022 \\
106\end{array}$ \\
\hline
\end{tabular}

**. Correlation is significant at the 0.01 level (2-tailed).

*. Correlation is significant at the 0.05 level (2-tailed).

\subsection{Correlation Matrix of CSR to employees and customers towards employees' commitment}

It investigated the relationship between CSR perception by employees (in terms of CSR to employees) and to customers (measured CSR to customers) and the commitment of employees (as total employee commitment). The perceived employees were positively correlated with the commitment of the employees $(r=0,237,0,209, n=106, p<$ $0,05)$ with high levels of both of these variables related to the commitment of employees.

Table 4. Correlation Matrix between CSR to environment and community towards Employees' Commitment

\begin{tabular}{|c|c|c|}
\hline & & $\begin{array}{l}\text { Total } \\
\text { employees' } \\
\text { commitment }\end{array}$ \\
\hline CSR to employees & $\begin{array}{l}\text { Pearson Correlation } \\
\text { Sig. (2-tailed) } \\
\mathrm{N}\end{array}$ & $\begin{array}{l}.237^{* *} \\
.014 \\
106\end{array}$ \\
\hline CSR to customers & $\begin{array}{l}\text { Pearson Correlation } \\
\text { Sig. (2-tailed) } \\
\mathrm{N}\end{array}$ & $\begin{array}{l}.209^{*} \\
.031 \\
106\end{array}$ \\
\hline
\end{tabular}

**. Correlation is significant at the 0.01 level (2-tailed).

*. Correlation is significant at the 0.05 level (2-tailed).

\section{Regression Analysis}

The regression analyses are based on the measurement analyzed from previously analyzed correlations between variables, but regression allows the interaction between the variables to be more sophisticated. It can also show how many variables a certain outcome can be predicted. We use a pattern to predict the dependent variable's value from one or more independent variables in regression analysis. In this investigation, the value of the dependent variable is determined by multiple regression analysis (more than one prediction).

To evaluate the link between the socially responsible perception of employees as regards the impact on employees, consumers, the environment, and the community on their commitment to the organization, a standard regression analysis was used. All independent variables (or predictors) are entered simultaneously in the equation under standard multiple regressions. In addition to those offered by all other independent variables, each independent variable is evaluated by its predictive power.

\subsection{Regression Analysis between CSR to employees and CSR to customer and Employees' Commitment}

The R2 value from the table describes the level of variation in the dependent variable (Employee Commitment), explaining the model which covers the CSR - employee variables, CSR-customer variables. In this case, the amount is 0.294, describing the total variables in the dependent variable by 29.4 percent of the independent variables, which are CSR to employees and CSR for customers. Moreover, in this study, $70.6 \%$ of the remaining variables were unclear 
because other undefined variables were possible that were not covered by this study and could explain the variable dependent. The $\mathrm{R}$ coefficient represented the correlation between the dependent variable, and the R-value here shows that the correlation between the variables was positive of 0.542 . The $\mathrm{R} 2$ is set to 0.281 . The p-value, as shown in the table of ANOVA, is less than 0.05. This shows that the model is of significance.

Table 5. Model Summary for Employees' Commitment

\begin{tabular}{c|c|c|c|c}
\hline Model & $\mathrm{R}$ & $\mathrm{R}$ Square & $\begin{array}{c}\text { Adjusted R } \\
\text { Square }\end{array}$ & $\begin{array}{c}\text { Std. Error of the } \\
\text { Estimate }\end{array}$ \\
\hline 1 & $.542^{\mathrm{a}}$ & .294 & .281 & 10.35502 \\
\hline
\end{tabular}

a. Predictors: (Constant), CSR to employees, CSR to customers

b. Dependent Variable: Employee commitment

Table 6. ANOVA for Employees' Commitment

\begin{tabular}{c|c|c|c|c|c|c}
\hline Model & & Sum of squares & df & Mean square & F & Sig. \\
\hline \multirow{2}{*}{1} & Regression & 4604.626 & 2 & 2302.313 & 21.472 & $.000^{\mathrm{a}}$ \\
& Residual & 11044.317 & 103 & 107.226 & & \\
& Total & 15648.943 & 105 & & & \\
& & & & & \\
\hline
\end{tabular}

a. Predictors: (Constant), CSR to employees, CSR to customers

b. Dependent Variable: Employee commitment

The table explains the tolerance and VIF value of the statistics of collinearity. The value for tolerance indicates the level of variability of the independent variable that the other separate variable does not explain. If this value is less than 0.10 , then several correlations suggest multicollinearity. VIF is the inverse of the tolerance value, indicating the multicollinearity if this value is greater than 10 . Therefore, in the present case, the value of tolerance is 0.999 , which is more than 0.10 , and the value of VI F less than 0.10 .

The p-value from the Sig is additional information we can obtain here. The p-value for variable CSR is shown 0.000 for employees, which is less than 0.05 , indicating that employees' prediction is significantly affected by the dependent variable. However, the p-value for the variable CSR is above 0.05 for customers, so that the variable does not contribute significantly to the prediction of the dependent variable.

The Part Correlation Coefficient is another information that can be summarized, which can explain each independent variable's unique contribution to the overall variation in the dependent variable. CSR to Employees correlates with part 0.541, which shows 29 percent of employee engagement variance after squaring the value. For CSR to customers, the value is 0.027 squared, giving the difference in employee commitment a very small contribution of 0.07 percent.

Table 7. Coefficients for Employees' Commitment

\begin{tabular}{|c|c|c|c|c|c|c|c|c|c|c|c|c|}
\hline \multirow[b]{2}{*}{ Model } & \multicolumn{2}{|c|}{$\begin{array}{l}\text { Unstandardized } \\
\text { Coefficients }\end{array}$} & \multirow{2}{*}{$\begin{array}{c}\text { Standardized } \\
\text { Coefficients } \\
\text { Beta }\end{array}$} & \multirow[b]{2}{*}{$\mathrm{t}$} & \multirow[b]{2}{*}{ Sig. } & \multicolumn{2}{|c|}{$\begin{array}{l}95.0 \% \text { Confidence } \\
\text { Interval for B }\end{array}$} & \multicolumn{3}{|c|}{ Correlations } & \multicolumn{2}{|c|}{$\begin{array}{l}\text { Collinearity } \\
\text { Statistics }\end{array}$} \\
\hline & B & $\begin{array}{l}\text { Std. } \\
\text { Error }\end{array}$ & & & & $\begin{array}{l}\text { Lower } \\
\text { Bound }\end{array}$ & $\begin{array}{l}\text { Upper } \\
\text { Bound }\end{array}$ & $\begin{array}{l}\text { Zero- } \\
\text { order }\end{array}$ & Partial & Part & Tolerance & VIF \\
\hline 1 (Constant) & 20.139 & 7.978 & & 2.524 & .013 & 4.315 & 35.962 & & & & & \\
\hline CSR to Employees & .633 & .097 & .541 & 6.531 & .000 & .441 & .826 & .542 & .541 & .541 & .999 & 1.001 \\
\hline CSR to Customers & .081 & .243 & .027 & .332 & .741 & -.401 & .562 & .045 & .033 & .027 & .999 & 1.001 \\
\hline
\end{tabular}

a. Dependent Variable: Employee Commitment

The unstandardized regression coefficient B of the table shows the strength of the relationship between the dependent and the independent variable, through which:

$$
\begin{aligned}
& \mathrm{Y}=\mathrm{a}+\mathrm{b} 1(\mathrm{X} 1)+\mathrm{b} 2(\mathrm{X} 2) \\
& \mathrm{Y}=\text { Employees' Commitment } \\
& \mathrm{a}=\text { constant value } \\
& \mathrm{b}=\text { standardized coefficient } \\
& \mathrm{X} 1=\text { CSR to Customers }
\end{aligned}
$$




\section{$\mathrm{X} 2=\mathrm{CSR}$ to Employees}

The regression equation is calculated below the stated variables, indicating that a CSR increase unit for CSR to customersand a CSR to employees increases; hence,

$$
\text { Employees' Commitment }=20.139+0.081(\text { CSR to Customers })+0.633(\text { CSR to Employees })
$$

This output also clarifies the level of impact of each independent variable on the dependent variable. The coefficient table describes the contributions made to the dependent variable by each variable. Therefore, CSR to employees is interpreted as contributing the greatest variation to the commitment of employees by representing the B value of 0.633 , whereas CSR to customers provides the lowest difference in the perception of employees by showing the P-value of 0.081 .

\subsection{Regression Analysis between CSR to Environment and CSR to Community and Employees' Commitment}

Table 8. Model Summary for Employees' Commitment

\begin{tabular}{c|c|c|c|c}
\hline & & & Adjusted R & Square \\
Model & $\mathrm{R}$ & R Square & $\begin{array}{c}\text { Std. Error of the } \\
\text { Estimate }\end{array}$ & \\
\hline 1 & $.691^{\mathrm{a}}$ & .477 & .467 & 7.60906 \\
\hline
\end{tabular}

a. Predictors: (Constant), CSR to employees, CSR to customers

b. Dependent Variable: Employee commitment

The $\mathrm{R} 2$ of the table is 0,477 , which describes that $47,7 \%$ of the dependent variable variables (Employee's commitment) can be explained by the independent variable (CSR to Environment and CSR to Community). However, this study explains the remaining 52.3 percent, which means other variables were not taken into account in this study, which can explain employees' commitment. The R-value is 0.691 , and the adjusted R2 value is 0.467 , which indicates solid positive correlations. The p-value of less than 0.000 is shown on the ANOVA table, which shows that the proposed model is successful.

Table 9. ANOVA for Employees' Commitment

\begin{tabular}{c|c|c|c|c|c|c}
\hline Model & & Sum of squares & df & Mean square & F & Sig. \\
\hline \multirow{2}{*}{1} & Regression & 5445.892 & 2 & 2722.946 & 47.030 & $.000^{\mathrm{a}}$ \\
& Residual & 5963.466 & 103 & 57.898 & & \\
& Total & 11409.358 & 105 & & & \\
& & & & & \\
\hline
\end{tabular}

a. Predictors: (Constant), CSR to Environment, CSR to Community

b. Dependent Variable: Employee Commitment

Table 10. Coefficients for Employees' Commitment

\begin{tabular}{|c|c|c|c|c|c|c|c|c|c|c|c|c|}
\hline \multirow[b]{2}{*}{ Model } & \multicolumn{2}{|c|}{$\begin{array}{l}\text { Unstandardized } \\
\text { Coefficients }\end{array}$} & \multirow{2}{*}{$\begin{array}{c}\text { Standardized } \\
\text { Coefficients } \\
\text { Beta }\end{array}$} & \multirow[b]{2}{*}{$\mathrm{t}$} & \multirow[b]{2}{*}{ Sig. } & \multicolumn{2}{|c|}{$\begin{array}{l}95.0 \% \text { Confidence } \\
\text { Interval for B }\end{array}$} & \multicolumn{3}{|c|}{ Correlations } & \multicolumn{2}{|c|}{$\begin{array}{c}\text { Collinearity } \\
\text { Statistics }\end{array}$} \\
\hline & B & $\begin{array}{l}\text { Std. } \\
\text { Error }\end{array}$ & & & & $\begin{array}{l}\text { Lower } \\
\text { Bound }\end{array}$ & $\begin{array}{l}\text { Upper } \\
\text { Bound }\end{array}$ & $\begin{array}{l}\text { Zero- } \\
\text { order }\end{array}$ & Partial & Part & Tolerance & VIF \\
\hline 1 (Constant) & 37.728 & 3.978 & & 9.485 & .000 & 29.839 & 45.616 & & & & & \\
\hline CSR to Environment & .687 & .199 & .286 & 3.457 & .001 & .293 & 1.080 & .539 & .322 & .246 & .743 & 1.346 \\
\hline CSR to Community & 1.401 & .231 & .501 & 6.060 & .000 & .943 & 1.860 & .645 & .513 & .432 & .743 & 1.346 \\
\hline
\end{tabular}

a. Dependent Variable: Total Organization Commitment

The statistics for collinearity in the table define the previously described tolerance and VIF value. This is a tolerance of 0.743 , a value of 0.10 , VIF of 1.346, and less than ten. This shows that the model breaches the assumption of multilinearity. Besides, both variables (CSR to Environment and CSR to Community). Results show that the p-value of less than 0.05 , which also indicates that the prediction of the employee commitments is related significantly and contributes to the dependent variable. 
The part correlation of CSR to Environment is 0.246, and after squared, the variance of employee commitment is indicated by 6.05 percent of this independent variable. CSR's correlation coefficient to the community is 0.432 , which is explained in the employee commitment when squeezed at 18.6 percent of the variance.

By using the following regression equation derived from the unnormalized regulation coefficient, B from the table, the strengthening of relationships between the dependent and independent variables can be explained.

$$
\begin{aligned}
& \mathrm{Y}=\mathrm{a}+\mathrm{b} 1(\mathrm{X} 1)+\mathrm{b} 2(\mathrm{X} 2) \\
& \mathrm{Y}=\text { Employees' Commitment } \\
& \mathrm{a}=\text { constant value } \\
& \mathrm{b}=\text { standardized coefficient } \\
& \mathrm{X} 1=\mathrm{CSR} \text { to Environment } \\
& \mathrm{X} 2=\mathrm{CSR} \text { to Community }
\end{aligned}
$$

The estimated regression equation of this linear relationship is therefore as follows. The estimate shows that the value of employee engagement will be enhanced if a unit of CSR to the environment and of CSR to the community is increased.

Employees' Commitment $=37.728+0.687(\mathrm{CSR}$ to Environment $)+1.401(\mathrm{CSR}$ to Community $)$

Thereafter, the CSR to Community is the highest-B value of 1.401, and the CSR to the Environment is the lowest-B value of 0.687 . This makes the least possible difference in employee commitment. CSR to the Community

\subsection{Correlation of the Variables}

The purpose of the correlation analysis is to determine whether a change in the independent variable would lead to a change in the dependent variable. A low coefficient for correlation (e.g., lower than \pm 0.10 ) suggests a weak or nonexistent relationship between the two elements. A high correlation coefficient indicates that the dependent variable usually changes when the variable is independent. The direction of the variable depends on the coefficient sign. The dependent variable moves in the same direction as the independent variable, where the positive value is indicated. If the coefficient is negative, the dependent variable moves in the opposite direction of the independent variable, which shows a negative correlation. For the four relationships indicated by the hypothesis of this study, a correlation analysis was conducted. The correlation of CSR perception by employees as far as environmental CSR is concerned with the community and the commitment of their employees has been analyzed. The perceived CSR with the environment was strong and positive in terms of commitment from employees to the Pearson correlation value of over 0.5 , which shows that these variables are very effective.

It has been a low but positive correlation between the perceived CSR's commitment to the community and the employees ' commitment to the Pearson value of less than 0.5. This results in a lesser impact or change in employee commitment than a perceived CSR on CSR's environment perceived by the community in the organization's CSR activities.

An analysis was also carried out of CSR's relationship to employees and CSR to the customers on employees' commitment. The CSR to employees and CSR to customers were less than 0.5, which shows that these two variables had less impact on employee commitment yet positive correlations. In other words, the correlation value of Pearson is less than 0.5 . A correlation matrix was presented between all of the analyzed variables to indicate the level of correlation and the direction of all of the variables involved in this trial.

Hypothesis 2 in this study, which was the positive connection between employee engagement and CSR's customer influence, was not supported because the results of the analysis show that the p-value was 0,731 (B-0,081), which shows that employees socially responsible CSR perceptions for customers did not achieve p-value. Hypothesis 1 of this research was supported because the results of the analysis demonstrated that the p-value was less than $0.05(\mathrm{~B}=0.633)$, which demonstrated that a positive contribution of the socially responsible perceptions of the CSR to employees was received by the employees with the employee commitment. There has also been support for the positive relationship between CSR to environment and the commitment of employees to the organization (Hypothesis 3$)(B=0,686$ (p $<0,05))$ and CSR to community (Hypothesis 4) $(\mathrm{B}=1,401, \mathrm{p}<0,05)$. The analysis results also show that the employees ' commitment described 29 percent of the variance in the socially responsible perceptions of the CSR, and the CSR described 0,07 percent of the dependent variable for the customers. Also, 19\% of CSR's variance to community and CSR to the environment were described as $6 \%$ of the variance.

Table 11 below presents an overview of the research issues with the results; the decision is taken to accept or refuse the null hypothesis. 
Table 11. Hypotheses Testing Results

\begin{tabular}{l|c|c}
\hline \multicolumn{1}{c|}{ Hypotheses } & P-value/Beta & Decision \\
\hline H1: & $\mathrm{p}=0.000$ & Reject H0 \\
H0: Impact of CSR to employees is associated negatively towards employees' \\
$\begin{array}{l}\text { commitment } \\
\text { H1: Impact of CSR to employees is associated positively towards employees' } \\
\text { commitment }\end{array}$ & $\mathrm{B}=0.633$ & Accept H1 \\
\hline $\begin{array}{l}\text { H2: } \\
\text { H0: Impact of CSR to customers is associated negatively towards employees' } \\
\text { commitment }\end{array}$ & $\mathrm{p}=0.741$ & Reject H1 \\
$\begin{array}{l}\text { H1: Impact of CSR to customers is associated positively towards employees' } \\
\text { commitment }\end{array}$ & $\mathrm{B}=0.081$ & Accept H0 \\
\hline $\begin{array}{l}\text { H3: } \\
\text { H0: Impact of CSR to the environment is associated negatively towards } \\
\text { employees' commitment }\end{array}$ & $\mathrm{p}=0.00$ & Reject H0 \\
$\begin{array}{l}\text { H1: Impact of CSR to the environment is associated positively towards } \\
\text { employees' commitment }\end{array}$ & $\mathrm{B}=0.687$ & Accept H1 \\
\hline $\begin{array}{l}\text { H4: } \\
\text { H0: Impact of CSR to the community is associated negatively towards } \\
\text { employees' commitment }\end{array}$ & $\mathrm{p}=0.001$ & Reject H0 \\
$\begin{array}{l}\text { H1: Impact of CSR to the community is associated positively towards } \\
\text { employees' commitment }\end{array}$ & $\mathrm{B}=1.401$ & Accept H1 \\
\hline
\end{tabular}

\section{DISCUSSION OF STUDY RESULTS}

After testing the reliability of the variables used in this study (Employees' Commitment in terms of CSR to Environment (EN), and CSR to Community (CO), CSR to the employees (EM), and CSR to the Customers (CU), the result indicates that most of the constructs were consistent internally. In other terms, these constructs' elements have been reliable to evaluate the employees' commitment to the organization.

All constructs have had overall reliability of more than 0.6 ; however, the CSR to community construct only scored 0.598 less than 0.6 . This indicates that a certain item $(\mathrm{CO} 14)$ is not strongly related to the total scale and resulted in an acceptable score above the cut-off point after this particular item has been removed from the construct. However, CSR to the Community has the lowest reliability score in comparison with other structures. That is why employees probably do not understand that their organization is more interested than involved as individuals in supporting CSR to their community in supporting CSR.

The above item was subsequently removed, and the reliability of the CSR was reassessed. Therefore, this construct's reliability value was to be more than 0.60 after removing the specific item, which explains the internal consistency of the construct. Another reliability analysis was performed after this modification was made as well.

\section{Assumptions, Limitations \& Suggestion for Future Research}

Research requires assumptions, limitations, and delimitations to make sure the study is valid and reliable. The validity and reliability of a study are doubtful without assumptions, limitations, and delimitations. To show the validity and reliability of my study, I discussed assumptions, limitations, and delimitations.

\subsection{Assumptions}

In research, assumptions are not part of what is being tested (Gravetter et al., 2020). I assumed that participants were honest, open, and inclusive of their participation in companies' social and ethical activities. I assumed leaders were also somewhat familiar with or concerned with the CSR initiatives of this organization and understood the referenced fundamental activities or programs related to CSR. There was no account of the management's or other external parties ' negative influence.

Therefore, commitment and associated structures are external and can be described and measured at the individual level. Self-reports of the study's constructs of interest are reliable and accurate enough to justify the exploration of the interrelationship between the constructs in question.

For statistical purposes, ordinary levels of data obtained through self-reporting surveys can be processed as an interval level without prejudice to the conclusions reached that the measured variables were instability through a quantitative cross-sectional study. For instance, the examination of relations between variables assumes certain directions, that CSR influences commitment rather than commitment influences CSR. The inability to examine causal relationships through cross-sectional studies is well known, but it is experimentally and philosophically difficult to establish causality in 
untrivial social and behavioral studies regardless of the research designs used (Sobel, 1995). Therefore, it is assumed that a cross-sectional survey conducted as a theory test can enhance our understanding of the commitment domain when complemented with qualitative research.

\subsection{Limitations}

There are several limitations to this research study, which are essential for an accurate assessment of the results. First, in the responses of the respondents, there is a potential limitation of bias. Employees' views or statements could most likely have been expressed impartially because their replies were meant to answer the questions as to what they were asked by the person who sent the survey form, and subsequently, the employees did not take such details into account. The questionnaire could be answered only by those familiar with the English language, and the respondents' information is presumed true.

The indecisive approach of employees, such as the tendency to respond, is considered appropriate and is in response to the fact that it is most likely undesirable or not appropriate in an organizational setting because this is commonly called the methodological bias. The forecaster methods and standard variables can be avoided by controlled all processes collected from various sources, which can be avoided. Besides, as a result of the correct direction of these structures, respondents were less expected to respond in the same manner to comparable elements.

Results from previous studies in various geographical areas show that CSR does not significantly influence government commitment. Thus, CSR to the government as an independent variable was excluded from the research considering the study's time and scale limits.

Time and financial constraints are other limitations of this study. The overall schedule is around seven months to complete this study. Practically speaking, this may not be an ideal timeframe for a research study, and the sample size that could be collected has therefore been relatively small. It is, therefore, essential that adequate data be collected to cultivate a research study. It is also important to access quality data to provide consistent and accurate information. However, it is nevertheless essential to buy some online journals and publications that everyone can access.

Similarly, the data collected in this study were cross-sectional, which occurred at once, and this information is a single sample. There was limited availability of sampling techniques for the entire population comprising the respondents who eventually volunteered to contribute to the study. As each person in the population is not required to participate in the sample, the comfort sample results cannot be generalized to the population of interest. In this research study, the convenience sampling method was used to attract a casual sample from the intended population.

Furthermore, this study's sample size was quite small since only a specific number of respondents should complete the survey questionnaire of certain sets of survey questionnaires to be distributed through online and conventional survey forms. Since the study focuses on a specific industry in Libya, namely the construction industry, the sample size may not be imprecise to indicate the population, and the perceptions of employees also focused on this particular study. Furthermore, the sample size may not be significant for the whole Libyan population due to the target population in data collection is limited within certain areas in Libya. Therefore, these respondents ' opinions could not accurately characterize the views of the employees for the construction of people in Libya. The study is applied to Libya's construction companies; performing the study in other industrial sectors is essential to complete the puzzle of the CSR influence. The study is to be carried out in Libya, with various results in other countries or companies. Consequently, it is welcome for other scholars to replicate the study in other environments.

\subsection{Recommendations for Future Research}

Future research might be coordinated to talk about the confinements characterized previously. Since this examination concentrated bleeding-edge employees inside the development business in Libya, future investigations may extend the examination to various divisions to achieve the investigation results' outline. Besides, inside and out meetings with representatives would be valuable, particularly because CSR practices may separate as per various businesses. Backing from the administration, the struggle of individual enthusiasm, working conditions, environment, and community welfare, go along to all customer's rights, the structure of compensation is a portion of the precedents that are skilled to impact the representatives' dedication and subsequently, it is reasonable to be sure that different factors influence the relationship between the ones that were concentrated in this exploration ponder. This may support downplay by what implies CSR rehearses influence employee's commitment to the association. Future research may rethink the hypothetical model utilized in this examination with a bigger example measure so the results can be broad to a bigger populace. As discussed in the past, representatives see CSR to employees decidedly towards their exhibition since they may see that CSR has any effect on their authoritative execution. In any case, the establishment of the relationship between CSR and CSR to customers has been scarcely investigated. In this manner, it is huge and profitable for future investigations to precisely look at precisely how tedious it continues for CSR's impact to representatives, customers, environment, and community on employees' duty to the association to be found to decide if this relationship holds reliably after some time. A positive impact on the relationship between the employees' commitment and CSR to the environment alongside CSR to the community was found in this exploration examination. Future investigations could evaluate if there is a presence of 
various dimensions of employee duty and if such dimensions affect the representatives' impact towards CSR to the environment and CSR to the community. These two factors are essential to inquire about further because of the way that CSR to environment underpins the productive and powerful working of associations' commitments to the prosperity of encompassing environment and CSR to community adds to the accomplishment of social exercises bolstered by the association for the community welfare subsequently both coming about to energy in representatives' commitment to the association in Libya. For instance, employees with a high duty towards their association might be engaged with a few of the associations' advanced CSR activities, yet employees with low commitment will once in a while or not get engaged in these CSR activities by any means. Besides, most likely, different viewpoints, for example, sexual orientation, age, residency, and authoritative dimension, impact employees' impression of CSR. For instance, official directors may have a hopeful impression of CSR activities since they are responsible for making CSR-related goals while employees don't have any investment in CSR-basic leadership so that they may distinguish CSR as a misuse of hierarchical assets. Approaching examinations should research assessments like this. At long last, future investigations may think about the impacts of other CSR activities, for example, the estimation of organization, acknowledgment to change and upheaval, authoritative design, and the executive's energy and professional stability on representatives' responsibility towards their association.

\section{References}

Abugre, J. B., \& Anlesinya, A. (2019). Corporate social responsibility and business value of multinational companies: lessons from a Sub-Saharan African environment. Journal of African Business, 20(4), 435-454.

Ahmad, S. H. (2017). An Exploratory Study of Recruitment and Selection System of Administration Staff in the Public Sector Universities of Khyber Pakhtunkhwa. Institute of Management Sciences, Peshawar.

Ali, W., \& Frynas, J. G. (2018). The role of normative CSR-promoting institutions in stimulating CSR disclosures in developing countries. Corporate Social Responsibility and Environmental Management, 25(4), 373-390.

Allen, N. J., \& Meyer, J. P. (1996). Affective, continuance, and normative commitment to the organization: An examination of construct validity. Journal of Vocational Behavior, 49(3), 252-276.

Alkadash, T. (2020). Mediating Role between Authentic Leadership, Organizational Commitment on Talents Turnover Intention: in Palestine Higher Education. TEST Engineering \& Management, 83, 5320-5341.

Argyris, C. (1998). Empowerment: The emperor's new clothes. Harvard Business Review, 76, 98-105.

Buchanan, B. (1974). Building organizational commitment: The socialization of managers in work organizations. Administrative Science Quarterly, 533-546.

Callan, S. J., \& Thomas, J. M. (2011). Executive compensation, corporate social responsibility, and corporate financial performance: A multi-equation framework. Corporate Social Responsibility and Environmental Management, 18(6), 332-351.

Carroll, A. B. (1979). A three-dimensional conceptual model of corporate performance. Academy of Management Review, 4(4), 497-505.

Carroll, A. B. (1991). The pyramid of corporate social responsibility: Toward the moral management of organizational stakeholders. Business Horizons, 34(4), 39-48.

Dong, H. (2016). Collaborating to develop: a perspective on current Chinese social partnership development: a thesis presented in partial fulfilment of the requirements for the degree of Doctor of Philosophy in Marketing at Massey University, Albany, New Zealand. Massey University.

Gravetter, F. J., Wallnau, L. B., Forzano, L.-A. B., \& Witnauer, J. E. (2020). Essentials of statistics for the behavioral sciences. Cengage Learning.

Jain, A., Leka, S., \& Zwetsloot, G. I. J. M. (2018). Mainstreaming Health, Safety and Well-Being. In Managing Health, Safety and Wellbeing (pp. 175220). Springer.

Kanter, M., \& Schneider, C. G. (2013). Civic learning and engagement. Change: The Magazine of Higher Learning, 45(1), 6-14.

Kesse Appiah, Z. (2020). The impact of leadership styles on employees' job performance: XYZ organization in Ghana.

Kim, H.-R., Lee, M., Lee, H.-T., \& Kim, N.-M. (2010). Corporate social responsibility and employee-company identification. Journal of Business Ethics, 95(4), 557-569.

Li, H., Zhang, X., Ng, S. T., \& Skitmore, M. (2018). Quantifying stakeholder influence in decision/evaluations relating to sustainable construction in China-A Delphi approach. Journal of Cleaner Production, 173, 160-170.

Lindgreen, A., Maon, F., \& Vallaster, C. (2016). Building Brands via Corporate Social Responsibility. Routledge.

Mazutis, D. D., \& Slawinski, N. (2015). Reconnecting business and society: Perceptions of authenticity in corporate social responsibility. Journal of Business Ethics, 131(1), 137-150.

Meyer, J. P., \& Allen, N. J. (1991). A three-component conceptualization of organizational commitment. Human Resource Management Review, 1(1), 61-89.

Meyer, J. P., Allen, N. J., \& Gellatly, I. R. (1990). Affective and continuance commitment to the organization: Evaluation of measures and analysis of concurrent and time-lagged relations. Journal of Applied Psychology, 75(6), 710.

Meyer, J. P., Allen, N. J., \& Smith, C. A. (1993). Commitment to organizations and occupations: Extension and test of a three-component conceptualization. Journal of Applied Psychology, 78(4), 538.

Meyer, J. P., Becker, T. E., \& Van Dick, R. (2006). Social identities and commitments at work: Toward an integrative model. Journal of Organizational Behavior: The International Journal of Industrial, Occupational and Organizational Psychology and Behavior, 27(5), 665-683.

Meyer, J. P., \& Maltin, E. R. (2010). Employee commitment and wellbeing: A critical review, theoretical framework and research agenda. Journal of Vocational Behavior, 77(2), 323-337.

Misani, N. (2017). The role of motive attributions of corporate social responsibility activities in the development of stakeholder trust. Proceedings of the International Association for Business and Society, 28, 191-203.

O’Reilly, C. A., \& Chatman, J. (1986). Organizational commitment and psychological attachment: The effects of compliance, identification, and internalization on prosocial behavior. Journal of Applied Psychology, 71(3), 492.

Olander, S., \& Landin, A. (2005). Evaluation of stakeholder influence in the implementation of construction projects. International Journal of Project Management, 23(4), 321-328.

Parra, C. M., Tremblay, M. C., \& Castellanos, A. (2016). Prominent voices and prevalent discourses: A corporate social responsibility application. 2016 Eleventh International Conference on Digital Information Management (ICDIM), 74-78.

Sakurai, M., \& Hashimoto, S. (2009). Exploring the distinctive feature of social enterprise in Japan. 2nd EMES International Conference on Social Enterprise. Trento, Italy.

Schepers, J. J. L., Nijssen, E. J., \& Van der Heijden, G. A. H. (2016). innovation in the frontline: Exploring the relationship between role conflict, ideas for improvement, and employee service performance. International Journal of Research in Marketing, 33(4), 797-817.

Sobel, M. E. (1995). Causal inference in the social and behavioral sciences. In Handbook of statistical modeling for the social and behavioral sciences 
(pp. 1-38). Springer.

Solinger, O. N., Van Olffen, W., \& Roe, R. A. (2008). Beyond the three-component model of organizational commitment. Journal of Applied Psychology, 93(1), 70.

Walton, C. C. (1967). Corporate social responsibilities. Wadsworth Publishing Company.

Werther Jr, W. B., \& Chandler, D. (2010). Strategic corporate social responsibility: Stakeholders in a global environment. Sage. 